Discussion Paper 85

Institute for Empirical Macroeconomics

Federal Reserve Bank of Minneapolis

Research Department

P.O. Box 291

Minneapolis, Minnesota 55480-0291

May 1993

\title{
Endogenous Expenditures on Public Schools and Persistent Growth
}

\author{
Gerhard Glomm and B. Ravikumar
}

University of Virginia

\begin{abstract}
In this paper, we present a model where individuals accumulate human capital through the formal schooling. To take into account the large involvement of the public sector in education we introduce a government which collects taxes from households and provides inputs to the learning technology. In our model the public expenditures on schools and growth rates are determined endogenously. Under plausible restrictions on the parameters of our model, we show that the predictions of our model qualitatively match the observations on per capita income, years of schooling, public expenditures on education and studentteacher ratios.
\end{abstract}

Please send all correspondence to: B. Ravikumar, Department of Economics, University of Virginia, Rouss Hall, Charlottesville, Virginia 22901.

*We would like to thank Alex Wolman and Anne Gulati for excellent research assistance. Financial support from the Bankard Fund is gratefully acknowledged. Any opinions, findings, conclusions, or recommendations expressed herein are those of the authors and not necessarily those of the National Science Foundation, the University of Minnesota, the Federal Reserve Bank of Minneapolis, or the Federal Reserve System. 


\section{Introduction}

Going back as far as the classical economists, such as Smith and Ricardo, the question of economic growth has been an important part of economic analysis. Following Arrow (1962), Razin (1972) and Uzawa (1965), recent models of Romer (1986) and Lucas (1988) emphasize human capital investment as an important factor contributing to long-run growth. Both Romer and Lucas determine the rate of long run growth endogenously by individuals' decisions to accumulate human capital. They generate persistent growth through socially non-decreasing returns to human capital accumulation.

In the recent growth literature, human capital investment takes several forms. In Stokey (1988) and Young (1991) human capital is accumulated through learning by doing. In Prescott and Boyd (1987) and Glomm (1992), it is accumulated by setting aside time to access other workers' expertise. In Jones and Manuelli (1990) and Rebelo (1991), savings are converted one-for-one into composite human-physical capital investment; persistent growth is obtained by positing a production function essentially linear in this composite capital.

Our main focus in this paper is on human capital accumulation through formal schooling. We are motivated by the observation that human capital accumulation through formal schooling is an important determinant of productivity levels and growth rates. Krueger (1968) has documented that approximately 50 percent of per capita income differences between countries can be explained by differences in years of schooling completed. Denison (1967) calculates that in the U.S. between 1950 and 1962, human capital investment measured in years of schooling accounts for 22 percent of productivity growth.

Given our emphasis on formal schooling, we need to take into account the large involvement of the public sector in education. In the U.S., for instance, 
over the last 100 years the fraction of students at the elementary and secondary level who attend public schools has never been below 86 percent (see figure 1). ${ }^{1}$ We model the role of the public sector as one of collecting taxes from households and providing inputs to the learning technology at zero price.

In Section II, we present some time series evidence on years of schooling, public expenditures on education, quality of public education and per capita income. Our aim is to construct a dynamic general equilibrium model to confront the empirical evidence.

In Section III, we describe an overlapping generations economy where human capital investment and public policy are endogenous. Human capital of each agent depends on time spent in schools, quality of schools and the stock of human capital of the agent's parents. All agents have a bequest motive and value the quality of education of their offspring. Tax revenues from a unfform tax on income are used to provide one of the inputs to the learning technology, namely, quality of schools. Individuals take public policies as given when making human capital investment decisions. The income tax rate chosen each period is the one that maximizes the welfare of old agents in the period.

Our model complements the literature on long run growth in which public policies are determined endogenously. This literature includes Barro (1990), Jones, Manuelli and Rossi (1991), Glomm and Ravikumar (1993) who examine endogenous public policies in representative agent economies; Persson and Tabellini (1990), Alesina and Rodrik (1990) and Glomm and Ravikumar (1992) where public policies are outcomes of a majority voting rule.

In Section IV, we characterize the human capital investment decisions and

1 In fact, for most OECD countries public school enrollment typically exceeds 70 percent. 
the public expenditures on education. We then provide conditions under which there is a unique equilibrium. Under these conditions we show that the implications of our model qualitatively match the 'stylized facts' presented in Section II. Section V contains concluding remarks.

\section{Some Empixical Evidence}

There are several features of the data that we would like to match qualitatively. In this section we briefly describe the data from three countries --- the U.S., the U.K. and Canada --- on per capita income, years of schooling, public expenditures on education and quality of public education. We focus on these three countries for reasons of data availability: we could obtain sufficiently long time series for the U.S., the U.K. and Canada. The data sources are described in the Appendix.

In figure 2, we illustrate the real per capita income time series for the U.S, the U.K. and Canada. In these three countries real per capita income exhibits persistent growth over the sample period.

Real per capita public expenditures on education are displayed in figure 3. This variable also exhibits persistent growth over the sample period in the three countries considered. In all three countries the share of income allocated to public expenditures on education has also increased substantially over time.

For the U.S., median years of school completed has increased steadily from 8 years at the turn of the century to over 12 years in 1980 (see figure 4, panel a). Other proxies such as average number of days attended per year and high school graduates as a fraction of the population are displayed in panel b and $c$. Both of these variables are increasing over time along with rising income in the 
U.S, Further, in all three countries, the fraction of 15-24 year olds who are full time university students has increased steadily over time (see figure 5). Figure 6 contains time series data for student-teacher ratios for the U.S., the U.K and Canada. In all three countries student-teacher ratios have declined significantly.

\section{The Environment}

Consider an overlapping generations economy with constant population where individuals live for two periods. Each generation consists of a continuum of identical agents. At time $t=0$, there is an initial generation of old agents in which each member is endowed with human capital $h_{0}$. We will normalize the size of each generation to unity.

Every agent born at $t=0,1,2, \ldots$ has identical preferences over leisure when young, consumption when old and bequest to hls off-spring. Formally, the preferences of an individual born at time $t$ are represented by

$$
\frac{1}{1-\sigma}\left\{n_{t}^{1-\sigma}+c_{t+1}^{1-\sigma}\right\}+\frac{1}{1-\phi} E_{t+1}^{1-\phi}, \quad \sigma, \phi>0
$$

where $n_{t}$ is lefsure at time $t, c_{t+1}$ is consumption at time $t+1$ and $e_{t+1}$ is quality of schools which his offspring attends at time $t+1$. As usual, if $\sigma$ or $\phi$ equals unity then the corresponding component of the utility function is assumed to be logarithmic.

Individuals are endowed with one divisible unit of time in their youth. Young individuals at time $t$ allocate $n_{t}$ units of their endowment towards leisure 
at time $t$ and devote the remaining $1-n_{t}$ units towards accumulating human capital according to

$$
\mathrm{h}_{\mathrm{t}+1}=\theta \mathrm{E}_{\mathrm{t}}^{\gamma} \mathrm{h}_{\mathrm{t}}^{\delta}\left(1-\mathrm{n}_{\mathrm{t}}\right), \quad \theta>0, \gamma, \delta \in(0,1) \text { and } \gamma+\delta-1
$$

where $h_{t}$ is the stock of human capital of the corresponding parent. We have assumed that the learning technology is linear in the time input purely for convenience. Both parental human capital and quality of public education exhibit diminishing returns to learning since $\gamma$ and $\delta$ are less than one. The restriction $\gamma+\delta=1$ is important for obtaining persistent growth as we shall see later.

Our assumption that quality of schools is an argument in the learning technology is similar to Lucas (1988). A discrete-time version of his technology may be written as $h_{t+1}-h_{t}=\delta\left(1-n_{t}\right) h_{t}$, where $\delta$ can be interpreted as the quality of education. In Lucas's model, $\delta$ is exogenous while in our model the quality is endogenous. On the empirical side, Heyneman (1984) provides some crosscountry evidence that school specific factors are positively related to various educational output measures. ${ }^{2}$

The use of parental human capital as an input in the learning function is consistent with a number of studies. Coleman et. al. (1966), for instance, found a positive correlation between parental education and performance on standardized tests in U.S. data.

At time $t+1$, each individual's income is assumed to be a linear function of his human capital:

2 For the U.S., see Hanushek (1986) on the impact of various measures of quality of education on test scores and graduation rates. 


$$
y_{t+1}=h_{t+1}
$$

The individual's earnings at time $t+1$ are taxed at the rate $\tau_{t+1}$.

We model public education as one where the government makes education available to all agents at zero price. Further, all agents have access to the same quality of education which is beyond the control of any one agent. Henceforth, we will denote the quality available to each agent by $\mathrm{E}$. We assume that the quality of public schools to be an increasing function of public expenditures per student. Total tax revenues determine the quality of public schools at time $t+1$ according to

$$
E_{t+1}=\tau_{t+1} Y_{t+1}
$$

where $Y_{t+1}$ is aggregate income at time $t+1$. Note that both quality of public schools and human capital are augmentable factors in our model and the learning technology exhibits constant returns to the augmentable factors.

There are two features of our model worth noting. First, we capture the social nature of learning emphasized by Lucas (1988): parents' human capital affects their children's learning. Second, the average stock of human capital is not directly productive in human capital accumulation or in final output. However, there is a spillover through the institution of public education.

The young agent's problem at time $t$ is, essentially, one of choosing $n_{t}$. Given the tax rate, parental human capital and the quality of public education, the choice of $n_{t}$ pins down $h_{t+1}, y_{t+1}$ and $c_{t+1}$. Formally, the individual's problem is to choose $n_{t}$ to maximize 


$$
\frac{1}{I-\sigma}\left\{n_{t}^{1-\sigma}+c_{t+1}^{1-\sigma}\right\}+\frac{1}{1-\phi} E_{t+1}^{1-\phi}
$$

subject to

$$
\begin{aligned}
& c_{t+1}=\left(1-\tau_{t+1}\right) h_{t+1}, \\
& h_{t+1}=\theta E_{t}^{\gamma} h_{t}^{\delta}\left(1-n_{t}\right), \\
& n_{t} \in[0,1], \\
& \text { given } E_{t}, h_{t}, E_{t+1} \text { and } \tau_{t+1} .
\end{aligned}
$$

In this maximization problem $E_{t}$ and $h_{t}$ are determined by the previous generation, whereas $E_{t+1}$ and $r_{t+1}$ are chosen only in old age. In the next period, we solve for each old agent's most preferred tax rate by maximizing

$$
\frac{1}{1-\sigma}\left(1-\tau_{t+1}\right)^{1-\sigma} y_{t+1}^{1-\sigma}+\frac{1}{1-\phi} x_{t+1}^{1-\phi} Y_{t+1}^{1-\phi}
$$

subject to $0 \leq r_{t+1} \leq 1$.

Note that the schooling decision made when young determines the income when old and hence, $\mathrm{Y}_{t+1}$ and $\mathrm{Y}_{t+1}$ are already determined when the old agent chooses his most preferred tax rate.

The solution to the above problem provides a natural analog to the outcome obtained by majority voting every period. Here we have assumed that only the old agents at time $t+1$ vote on tax rates. Of course, the voting problem is trivial in our model since all old agents are identical. We will, henceforth, refer to the above problem as the old voter's problem. 
The equilibrium for our economy is a set of sequences $\left\{n_{t}\right\}_{t=0}^{\infty},\left[h_{t+1}\right\}_{t=0}^{\infty}$, $\left\{c_{t}\right\}_{t=0}^{\infty},\left\{y_{t+1}\right\}_{t=0}^{\infty},\left\{Y_{t+1}\right\}_{t=0}^{\infty},\left\{E_{t}\right\}_{t=0}^{\infty}$ and $\left\{r_{t}\right\}_{t=0}^{\infty}$ such that

(1) $n_{t}, c_{t+1}, h_{t+1}$ and $y_{t+1}$ solve the optimization problem of a young agent born at time $t$,

(ii) individual income equals average income, $\mathrm{y}_{t+1} \Rightarrow \mathrm{Y}_{\mathrm{t}+1}$

(iii) $\tau_{t}$ is the tax rate most preferred by all the old agents at time $t$ and, (iv) the quality of public education at time $t, E_{t}-\tau_{t} Y_{t}$.

\section{Equilibrium}

Time Input to Learning

It can be easily verified that the objective function in the young agent's problem is strictly concave is $n_{t}$ and the feasible set is compact and convex. Hence, there exists a unique solution to the young agent's problem. We can solve for the young agent's time input to learning as

$$
1-n_{t}=\frac{\left\{\left(1-\tau_{t+1}\right) \theta E_{t}^{\gamma} h_{t}^{\delta}\right\}^{\frac{1-\sigma}{\sigma}}}{1+\left\{\left(1-\tau_{t+1}\right) \theta E_{t}^{\gamma} h_{t}^{\delta}\right\}^{\frac{1-\sigma}{\sigma}}} .
$$

We characterize the young agent's schooling choice in lemma 1 below. We have suppressed the time subscript for convenience.

Lemma 1 (i) If $\sigma$ is less than unity (greater than unity) then $1-n(\cdot)$ is decreasing (increasing) in $\tau$. 
(ii) If $\sigma$ is less than unity (greater than unity) then $1-n(\cdot)$ is an increasing (decreasing) function of the quality of public education $E$.

(iii) If $\sigma$ is less than unity (greater than unity) then $1-n(\cdot)$ is an increasing (decreasing) function of the parental human capital $\mathrm{h}$.

Proof To get the results (i), (ii) and (iii), differentiate (2) implicitly with respect to $\tau, E$ and $h$ respectively.

Q.E.D.

The intuition for lemma 1 is as follows. Any change in $\tau$, $E$ or $h$ not only changes the individual's net income but also alters the relative price of leisure. The condition $\sigma<1$ restricts the curvature of the utility function and ensures that the substitution effect dominates the income effect. The result in this case is intuitive -- higher tax rate reduces the time devoted to human capital accumulation; higher quality public schools and higher parental human capital increase the time input to learning.

It is important to note that although lemma 1 does not assume anything about the learning technology, our specification does play a role in parts (ii) and (iii). For instance, if quality of public schools and time input of the young agent are perfect substitutes in the learning technology then an increase in the quality generates only income effects which leads to an increase in the amount of leisure (a decrease in $1-n$ ). With our specification, the returns to time spent learning are increasing with the quality of public schools and the parental stock of human capital.

While we do not have an a priori reason to restrict $\sigma$, we can bring some micro evidence to bear on the implications for earnings $y$ through the time input 1-n. The case of $\sigma$ less than unity is consistent with Card and Krueger (1992) 
and Heckman and Hotz (1986). Card and Krueger find that, for the U.S., men educated in states with high average school quality have a higher return to additional years of schooling. Using data from Panama, Heckman and Hotz report that parental background is positively related to schooling returns. Henceforth, we will assume $\sigma$ to be less than unity.

Substituting the schooling choice from (2) into the learning technology (1) yields the human capital of each agent as

$$
h_{t+1}=\frac{\left\{\left(1-\tau_{t+1}\right)^{1-\sigma} \theta E_{t}^{\gamma} h_{t}^{\delta}\right\}^{\frac{1}{\sigma}}}{1+\left\{\left(1-\tau_{t+1}\right) \theta E_{t}^{\gamma} h_{t}^{\delta}\right\}^{\frac{1-\sigma}{\sigma}}} \cdot
$$

Given our earnings function, equation (3) also specifies each old agent's pre-tax income at time $t+1$.

\section{Public Policy}

At time $t+l$, the constraint set in the old voter's problem is clearly compact and convex. Each voter's objective function is strictly concave in the tax rate. Hence there exists a unique solution to the old voter's problem. It is also clear that the most preferred tax rate of each voter is in $(0,1)$. The equilibrium tax rate must satisfy the following condition:

$$
r_{\mathrm{t}+1}^{\phi} \mathrm{Y}_{\mathrm{t}+1}^{\phi-\sigma}=\left(1-\tau_{\mathrm{t}+1}\right)^{\sigma}
$$


In (4) we have used the fact that, in equilibrium, $y_{t+1}=Y_{t+1}$.

Existence and Uniqueness

To establish existence and uniqueness of equilibrium, we have to ensure that the agents' incomes implied by (3) are consistent with the tax rates implied by (4). We do this in the following proposition.

Proposition 1 If $\phi \leq \sigma$, there exists a unique equilibrium.

\section{$\underline{\text { Proof }}$}

Case 1: $\phi<\sigma$. For period 0 , there exists a unique $\tau_{0}$ which solves (4). There is no consistency problem for period 0 since the income in that period is exogenous.

Using (3), we can write the law of motion for aggregate income as

$$
Y_{t+1}=\frac{\left\{\left(1-\tau_{t+1}\right)^{1-\sigma} \theta E_{t}^{\gamma} Y_{t}^{\delta}\right\}^{\frac{1}{\sigma}}}{1+\left\{\left(1-\tau_{t+1}\right) \theta E_{t}^{\gamma} Y_{t}^{\delta}\right\}^{\frac{1-\sigma}{\sigma}}}
$$

Any tax-income pair $\left\{\tau_{t+1}, Y_{t+1}\right\}$ that simultaneously solves (4) and (5) is clearly an equilibrium. In the tax-income space, equation (5) describes a decreasing function whereas equation (4) describes an increasing function (see figure 7 ). Clearly, there exists a unique solution to (4) and (5).

Case 2: $\phi=\sigma$. In this case, equation (4) yields $\tau_{t}=\frac{1}{2}$ for all $t$ and the equilibrium obtained through (5) is clearly unique.

Q.E.D. 
We can find the equilibrium recursively as follows. We determine $\tau_{0}$ as the solution to

$$
r_{0}^{\phi} Y_{0}^{\phi-\sigma}=\left(1-\tau_{0}\right)^{\sigma}
$$

Using $\tau_{0}$ and $Y_{0}$, we can determine $E_{0}$. Using (4) and (5) we can determine $\tau_{1}$ and $Y_{1}$ simultaneously. Repeating this procedure yields $\left(\tau_{2}, Y_{2}\right),\left(\tau_{3}, Y_{3}\right)$ and so on. The time input to learning and the stock of human capital can be determined from equations (2) and (3) respectively. The after-tax income determines equilibrium consumption. Clearly, we cannot find an analytical solution to our model for arbitrary $\phi$ and $\sigma$ which satisfy the condition in proposition 1 . However, we can compute the equilibrium tax-income sequence numerically using the above procedure. We can then use the tax-income sequence to determine the other endogenous variables.

\section{Time Series Implications}

So far we have imposed the following restrictions on the parameters of our model: (i) $\theta>0, \gamma, \delta \in(0,1)$ and $\gamma+\delta-1$ and (ii) $0<\phi \leq \sigma<1$. Our model has joint time series predictions on (i) per capita income, (ii) public expenditures 'on education both in absolute terms and relative to per capita income, (iii) time allocated to formal schooling and (iv) quality of schools. Here we discuss if the predictions of our model qualitatively match the observations.

Our model predicts that per capita income $\left(Y_{t}\right.$ or $\left.H_{t}\right)$ will exhibit persistent growth if the scale parameter $\theta$ is sufficiently large. To see this we will consider the two cases $\phi<\sigma$ and $\phi=\sigma$ separately. When $\phi<\sigma$, equation 
(4) describes an increasing function in the tax-income space as indicated in panel a of figure 7. Note that the graph starts at the origin and approaches $\infty$ as $\tau$ tends towards one. Equation (5), on the other hand, defines a decreasing function. Note that given $\tau, Y$ and $E$, an increase in $\theta$ shifts the graph of equation (5) upward. Starting with an exogenous $Y_{0}$ we can find $\tau_{0}$ and $E_{0}$ using (4). The equilibrium tax-income pair $\left(r_{1}, Y_{1}\right)$ is the intersection of the two graphs in panel a. For $\theta$ sufficiently large, $Y_{1}$ exceeds $Y_{0}$. Clearly, $\tau_{1}$ must exceed $\tau_{0}$ and hence, $E_{1}$ is greater than $E_{0}$. Thus, the graph of equation (5) corresponding to $t=1$ is above the one corresponding to $t=0$. Therefore, the equilibrium tax-income pair $\left(\tau_{2}, Y_{2}\right)$ exceeds $\left(\tau_{1}, Y_{1}\right)$. Repeating this procedure we can find the entire sequence of tax-income pairs $\left\{r_{t}, Y_{t}\right\}$.

For $\phi<\sigma$, the evolution of per capita income, public expenditures on education, time allocated to schooling and share of output allocated to public expenditures on education are illustrated in figure 8. Our model implies that public expenditures on education increase over time as does aggregate income. This is roughly consistent with the time series pattern of per capita income and public expenditures for the three countries (see figures 2 and 3). Further, the share of income allocated to public expenditures on education, $\tau_{t}$, increases over time. Time allocated to schooling $1-n_{t}$ is increasing over time which is consistent with the data in figures 4 and 5 . The time series implications for quality of public education is the same as those for public expenditures on education. If one uses student-teacher ratio as a measure of quality then our model predicts that the ratios decline over time (see figure 6).

When $\phi=\sigma$, the graph of equation (4) is a vertical line at $\frac{1}{2}$ as indicated in panel $b$ of figure 7 . The equilibrium tax-income pairs are determined as in the previous case. The evolution of the endogenous variables is illustrated in 
figure 9. For $\phi=\sigma$, the predicted share of aggregate income allocated to public education is constant over time which is not consistent with the data.

As a theoretical matter, there may be multiple equilibria when $\phi>\sigma$. Further, our simulations indicate that persistent growth cannot be obtained for $\phi>\sigma$ unless there are sufficiently strong increasing returns to the augmentable factors in the learning technology. A careful investigation of these issues is beyond the scope of this paper.

\section{v. Concluding Remarks}

In this paper we have presented a simple model of human capital accumulation through formal schooling. Our model takes into account the involvement of the public sector in education by including a publicly provided input in the learning technology. We have established sufficient conditions for the existence and uniqueness of an equilibrium with endogenous public expenditures on schools. For plausible restrictions on the parameters of the learning technology and preferences, we have shown that the predictions of our model are roughly consistent with observations on years of schooling, public expenditures on education, school quality, and per capita income.

We discuss a few extensions of our model which may be interesting.

1. If the initial old are differentiated by their endowment of human capital, one could explore whether there are growth-inequality tradeoffs. With heterogeneity among the old voters, political mechanisms such as majority voting could be used to determine funding for public education. Such a model would yield predictions on how changes in income inequality affect both public expenditures and schooling decisions. 
2. In most economies public and private schools coexist. In an environment where all agents pay taxes to fund public education, allowing agents to buy educational services through competitive markets as an alternative to public education may have important consequences for long-run growth as well as the evolution of income inequality. A model with both private and public education could also be used to study the impact of different institutional descriptions of education on growth. For instance, one could consider alternative subsidy schemes such as voucher systems or user fees instead of direct public provision.

3. In less developed countries a large fraction of the school age children do not attend school at all even though public education is made available at zero price (see Psacharopoulos and Arriagada (1989)). Households that are close to subsistence levels may not find it in their interest to send their children to 'free' public schools since it may still entail large costs in terms of foregone wage income. Incorporating such opportunity costs into our model may be useful especially in the context of very poor countries. 
Appendix

Data Sources

The sources for the data in section II are as follows:

I. United States

Enrollment in public schools

1890-1970. U.S. Bureau of the Census. Historical Statistics of the United States: Colonial Times to 1970. Washington D.C.: U.S. Department of Commerce, 1975.

1972-1988. National Center for Education Statistics. Digest of Education Statistics. Washington D.C.: U.S. Government Printing Office, 1991.

GNP, Pub1ic expenditures

U.S. Bureau of the Census. Historical Statistics of the United States: Colonial Times to 1970. Washington D.C.: U.S. Department of Commerce, 1975.

Population

1870-1970. U.S. Bureau of the Census. Historical Statistics of the United States: Colonial Times to 1970. Washington D.C.: U.S. Department of Commerce, 1975.

1970-1988. U.S. Statistical Abstxact. Various Years.

Time allocated to schooling

U.S. Bureau of the Census. Historical Statistics of the United States: Colonial Times to 1970. Washington D.C.: U.S. Department of Commerce, 1975.

National Center for Education Statistics. Digest of Education Statistics. Washington D.C.: U.S. Government Printing Office, 1991.

U.S. Statistical Abstract. Various Years.

University students

1870-1975. Mitchell, B.R. International Historical Statistics of the Americas and Australia. Detroit: Gale Research Company, 1983.

1976-1988. U.S. Statistical Abstract. Various Years.

Student-teacher ratios

Mitchell, B.R. International Historical Statistics of the Americas and Australia. Detroit: Gale Research Company, 1983.

II. United Kingdom

$G D P$

Liesner, The1ma. Economic Statistics, 1900-1983: United Kingdom. United States of America, France, Germany, Italy, Japan. London: The Economist 
Publications, Ltd., 1985.

Public expenditures

(Central Government): Mitchell, B.R. British Historical Statistics.

Cambridge: Cambridge University Press, 1988.

(Local \& Municipal): Great Britain Annual Abstract of Statistics. London:

Central Statistical office, Various Years.

Population

Mitchell, B.R. British Historical Statistics. Cambridge: Cambridge University Press, 1988.

University students

1922-1975. Mitche11, B.R. European Historical Statistics: 1750-1975. New York: Facts on File, 1980.

1976-1980. Mitchel1, B.R. British Historical Statistics. Cambridge: Cambridge University Press, 1988.

Student-teacher ratios

1880-1975. Mitchell, B.R. European Historical Statistics: 1750-1975. New York: Facts on File, 1980.

1976-1988. Great Britain Annual Abstract of Statistics. London: Central Statistical office, 1990.

III. Canada

GNP

Leacy, F.H. ed. Historical Statistics of Canada. Ottawa: Statistics Canada, 1983.

Public expenditures

1926-1932. (Provincial Government). Urquhart, M.C., ed. Historical Statistics of Canada. Toronto: The MacMillan Company of Canada, Ltd.

1952-1974. (A11 Governments). Leacy, F.H. ed. Historical Statistics of Canada. Ottawa: Statistics Canada, 1983.

Population

Leacy, F.H. ed. Historical Statistics of Canada. Ottawa: Statistics Canada, 1983.

University students

1915-1920. The Canada Yearbook. Various Years.

1920-1976. Mitchel1, B.R. International Historical Statistics of the Americas and Australia. Detroit: Gale Research Company, 1983.

Student-teacher ratios

Mitchell, B.R. International Historical Statistics of the Americas and Australia. Detroit: Gale Research Co., 1983. 


\section{References}

Alesina, A. and D. Rodrik. "Redistributive Politics and Economic Growth." Manuscript. Harvard University, 1990.

Arrow, K. J. "The Economic Implications of Learning by Doing." Review of Economic Studies 29 (1962): 155-173.

Barro, Robert J. "Government Spending in a Simple Mode1 of Endogenous Growth." Journal of Political Economy 98, no. 5, pt. 2 (October 1990): s103-5125.

Card, D. and A. Krueger. "Does School Quality Matter? Returns to Education and the Characteristics of Public Schools in the United States." Journal of Political Economy (1992): 1-40.

Coleman, J., et al. Equality of Educational Opportunity. Washington D.C.: U.S. Government Printing Office, 1966.

Denison, E. F. Why Growth Rates Differ? Washington, D.C.: Brookings Institution, 1967.

Glomm, G. "A Model of Growth and Migration." Canadian Journal of Economics 25 (1992): $901-922$.

Glomm, G. and B. Ravikumar. "Public Investment in Infrastructure in a Simple Growth Mode1." Manuscript. Charlottesville: University of Virginia, 1993 (forthcoming in the Journal of Economic Dynamics and Control).

Glomm, G. and B. Ravikumar. "Public versus Private Investment in Human Gapita1: Endogenous Growth and Income Inequality." Journal of Political Economy 100 (1992): $818-834$.

Hanushek, E. "The Economics of Schooling: Production and Efficiency in Public Schools." Journal of Economic Literature 24 (September 1986): 1141-1177.

Heckman, J. J. and V. J. Hotz. "An Investlgation of the Labor Market Earnings of Panamanian Males: Evaluating Sources of Inequality." Journal of Human Resources 21 (1986): 507-542.

Heyneman, S. "Research on Education in Developing Countries." International Journal of Educational Development 4 (1984): 293-304.

Jones, L. E. and R. Manuelli. "A Convex Model of Equilibrium Growth: Theory and Policy Implications." Journal of Political Economy 98 (October 1990): 1008-1038.

Jones, L. E., Manue1li, R., and P. Rossi. "Optimal Taxation in Models of Endogenous Growth." Manuscript. Evanston: Northwestern University, 1991. 
Krueger, A. 0. "Factor Endowments and Per Capita Income Differences Among Countries." Economic Journal 78 (1968): 641-659.

Lucas, R. E., Jr. "On the Mechanics of Economic Development." Journal of Monetary Economics 22 (July 1988): 3-42.

Persson, T. and G. Tabellini. "Is Inequality Harmful for Growth?" Manuscript. Berkeley, University of California, 1990.

Prescott, E. and J. H. Boyd. "Dynamic Coalitions, Growth and the Firm," in Contractual Arrangements for Intertemporal Trade, Prescott, E. C. and N. Wallace (eds.). Minneapolis: University of Minnesota Press (1987).

Psacharopoulos, G. and A. M. Arriagada. "The Determinants of Early Age Human Capital Formation: Evidence from Brazil." Economic Development and Cultural Change 37 (1989): 683-708.

Rebelo, S. "Long-Run Policy Analysis and Long-Run Growth." Journal of Political Economy 99 (1991): 500-521.

Razin, A. "Investment in Human Capital and Economic Growth." Metroeconomica 24 (1972): 101-116.

Romer, P. "Increasing Returns and Long-Run Growth." Journal of Political Economy 94 (October 1986): 1002-1037.

Stokey, N. L. "Learning by Doing and the Introduction of New Goods." Journal of Political Economy 96 (1988): $701-717$.

Uzawa, H. "Optimum Technical Change in an Aggregative Model of Economic Growth." International Economic Review 6 (1965): 18-31.

Young, A. "Learning by Doing and the Dynamic Effects of International Trade." Quarterly Journal of Economics 106 (1991): 369-406. 


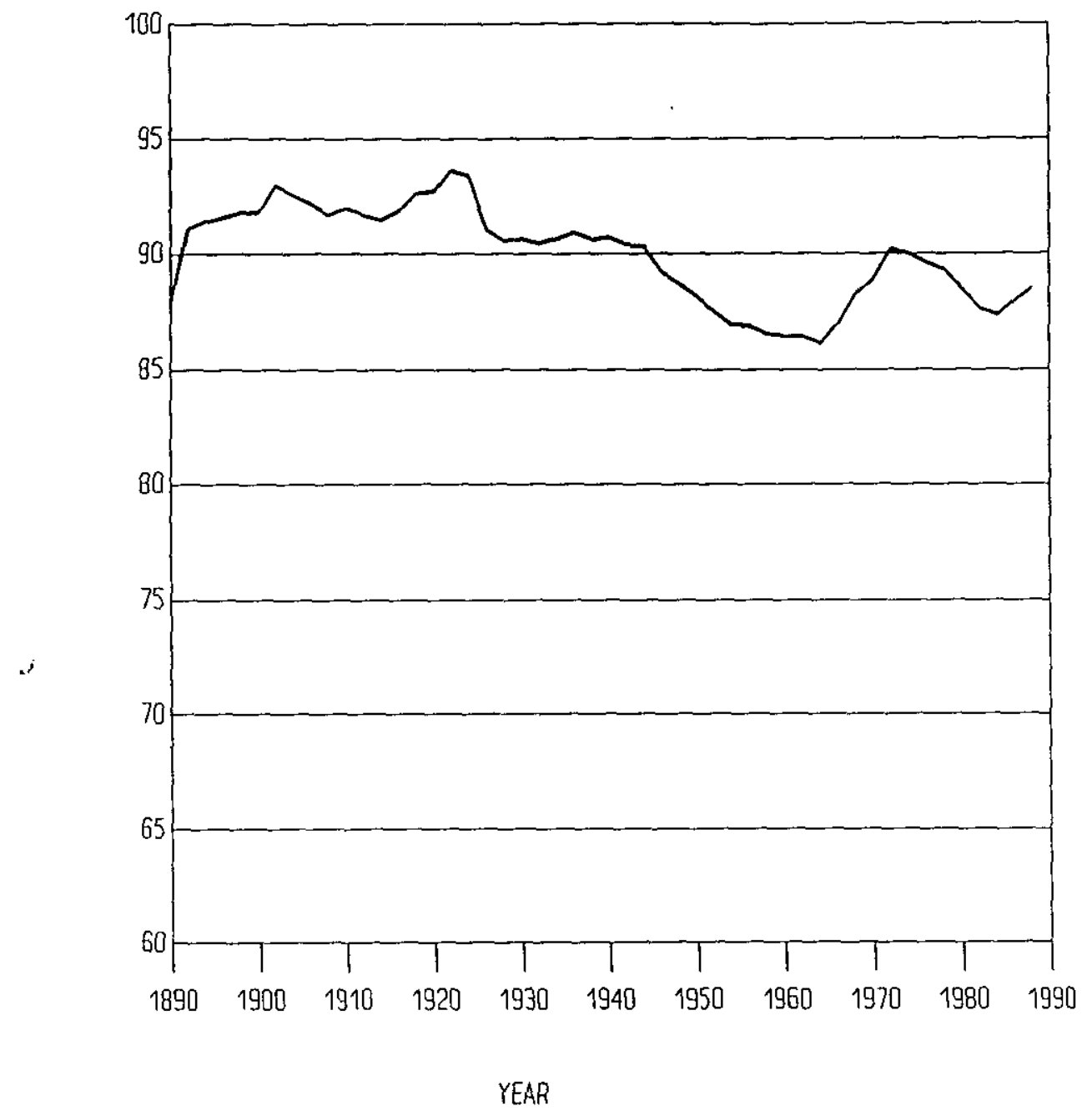

$* * *$ U.S.

- U.K.

H+ Canada

Figure 1. Percent of students enrolled in public schools 
Log per capita income

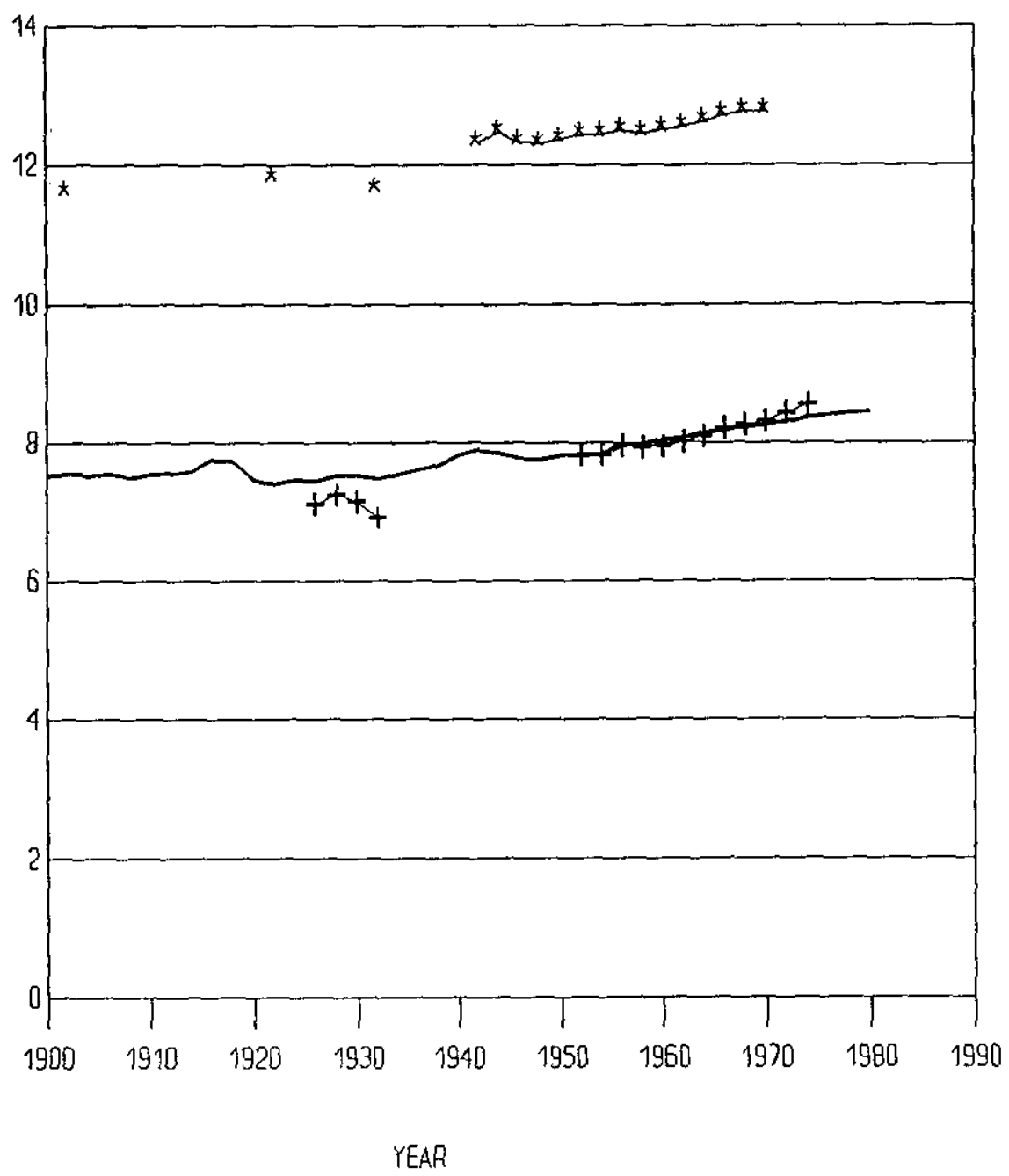

$\star \star *$ U.S.

- U.K.

+t+ Canada

Figure 2, Per capita income 
Log per capita public expenditure on education

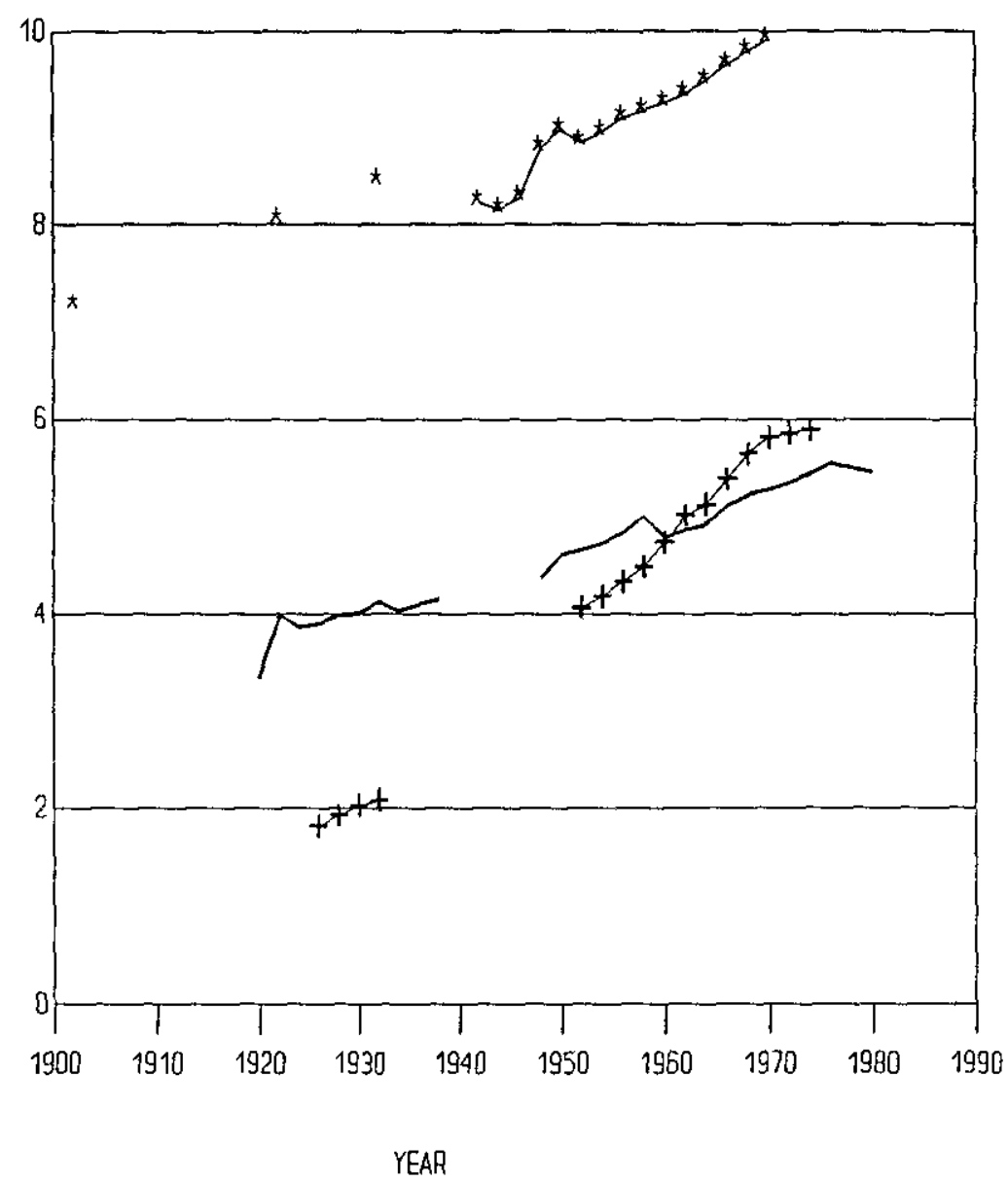

*** U.S.

- U.K.

++ Canada

Figure 3. Public expenditures on education 
a. Median years schooling

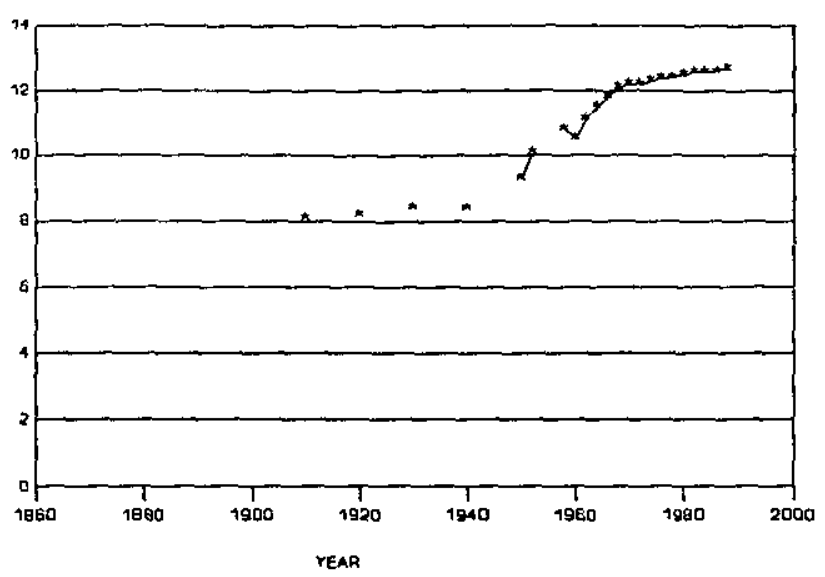

b. Average number of days attended

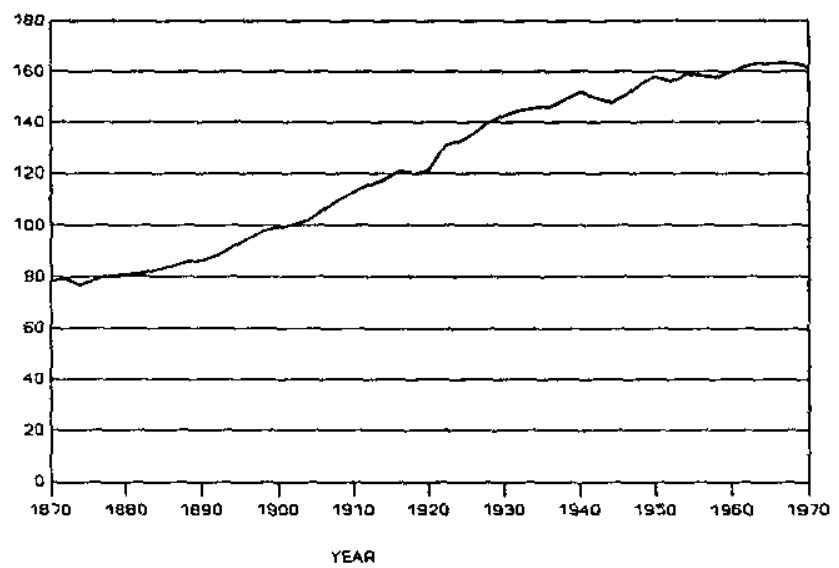

c. High school graduates as percent of population

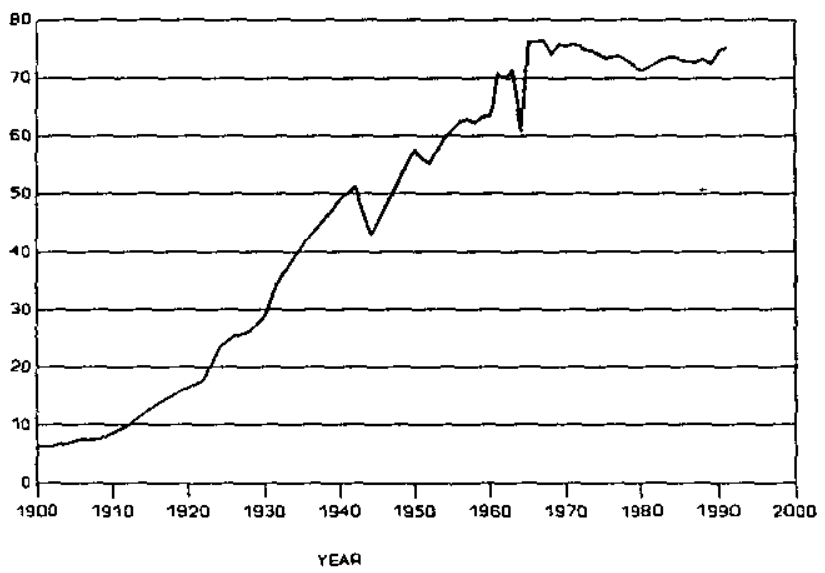

Figure 4. Time input to learning (U.S.) 


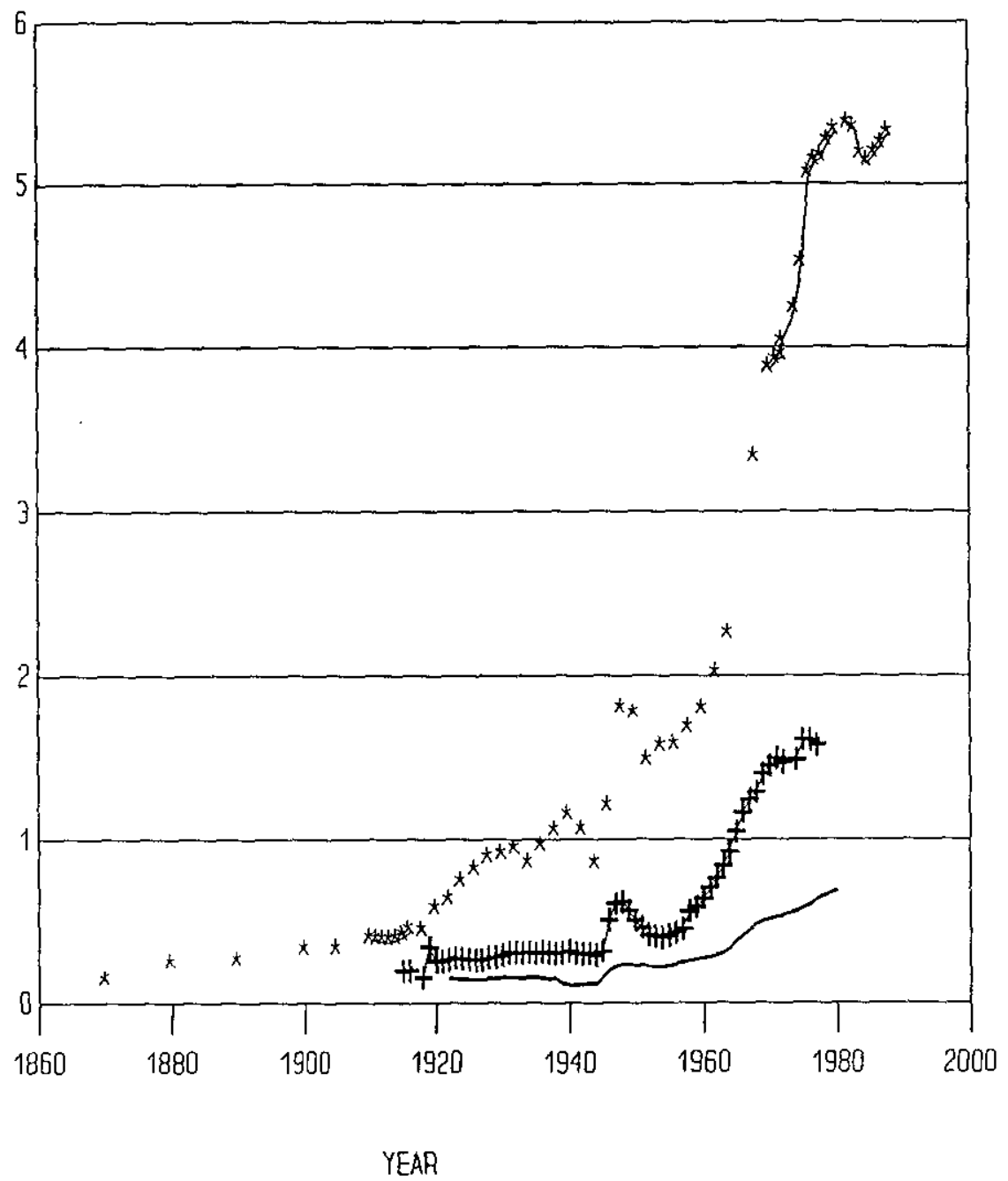

$* * *$ U.S.

- U.K.

++ Canada

Figure 5. College enrollment as percent of population 


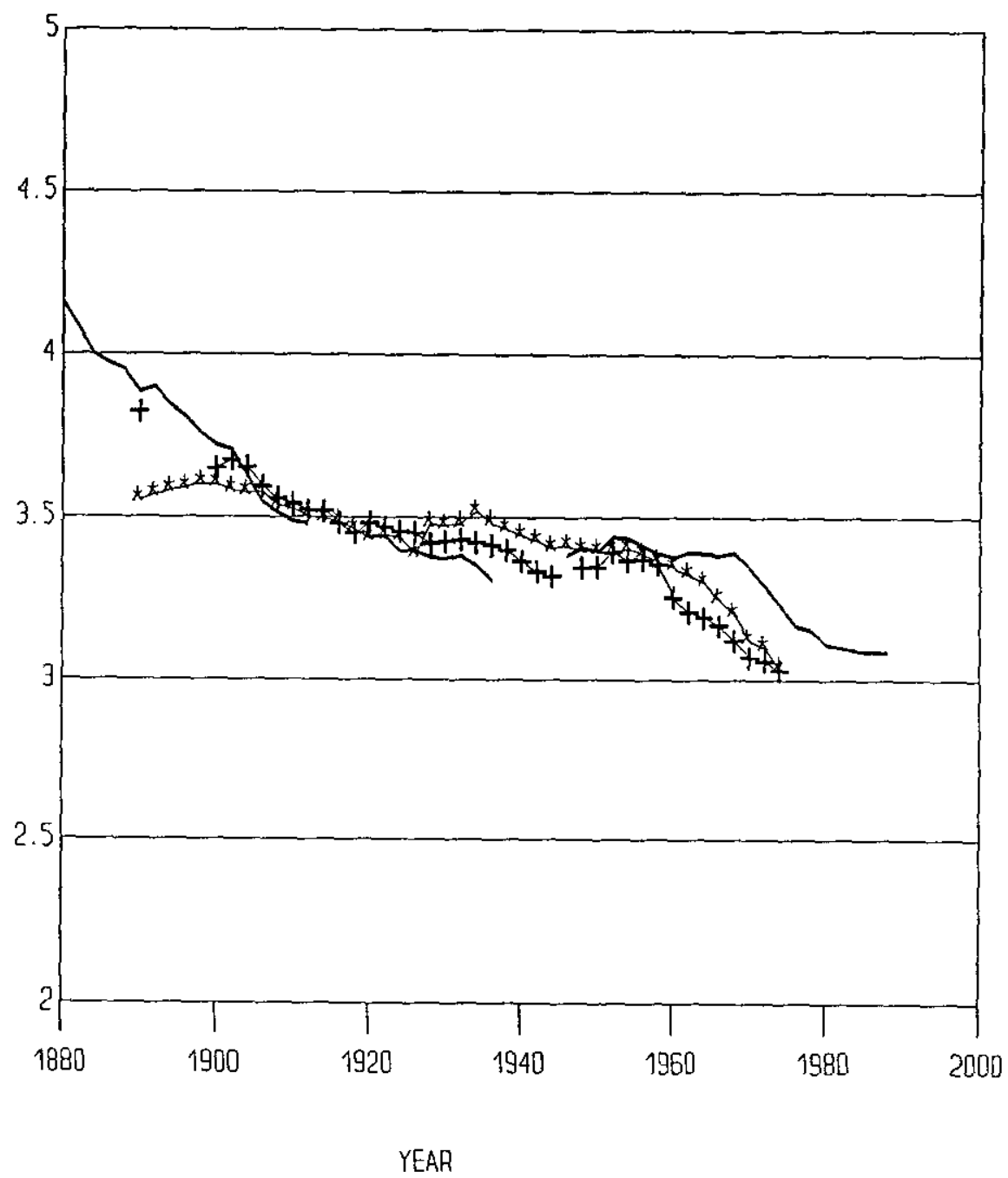

$\begin{array}{ll}* * * & \text { U.S. } \\ + & \text { U.K. } \\ +++ & \text { Canada }\end{array}$

Figure 6. Student-teacher ratios 
a. $\phi<\sigma$

Y

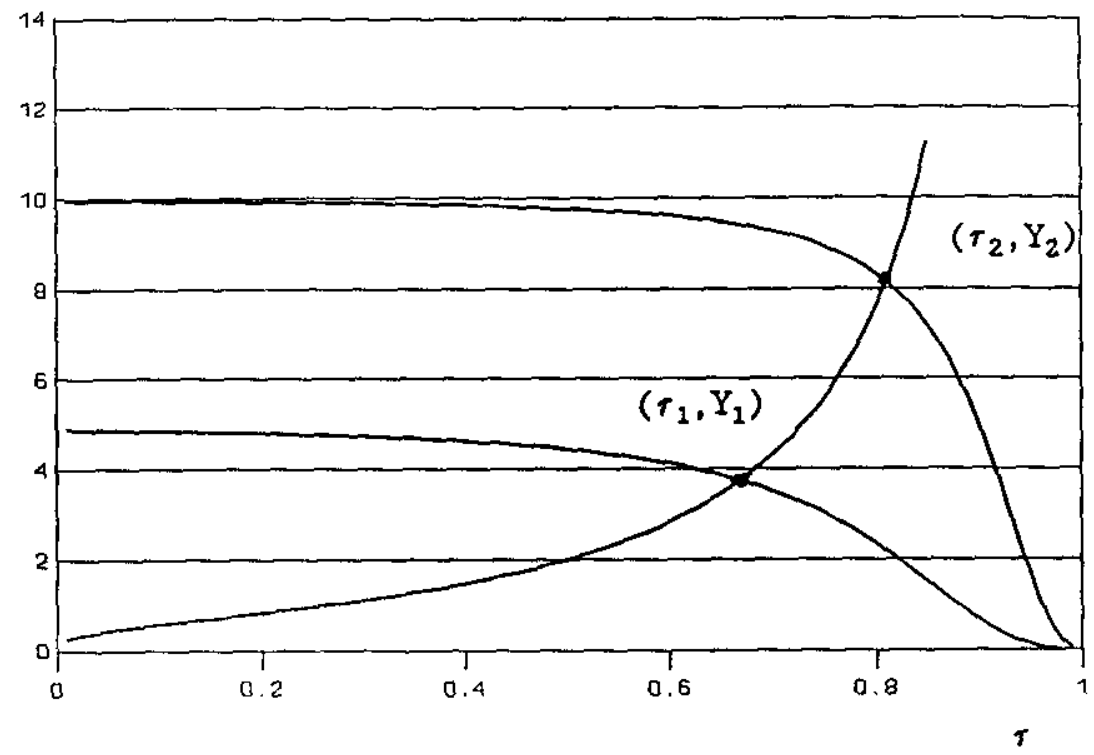

b. $\phi=\sigma$

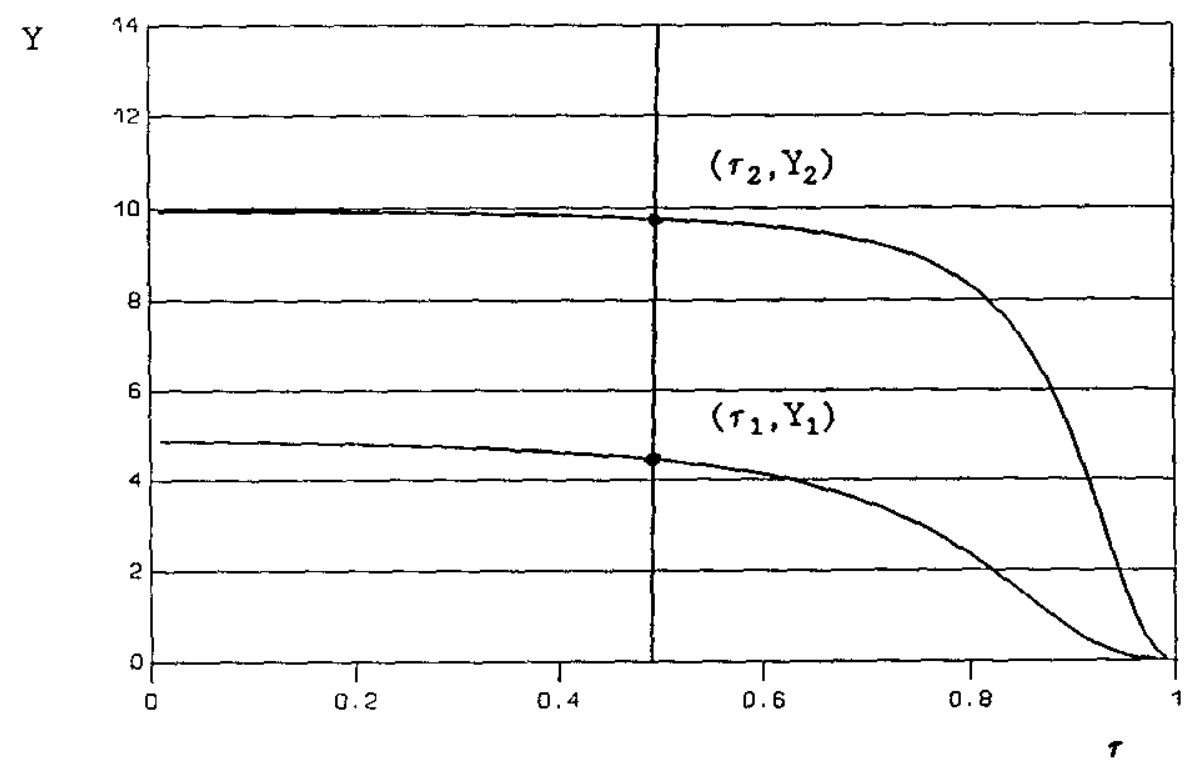

Figure 7. Equilibrium tax-income pairs 
a. Per capita income and public expenditures on education

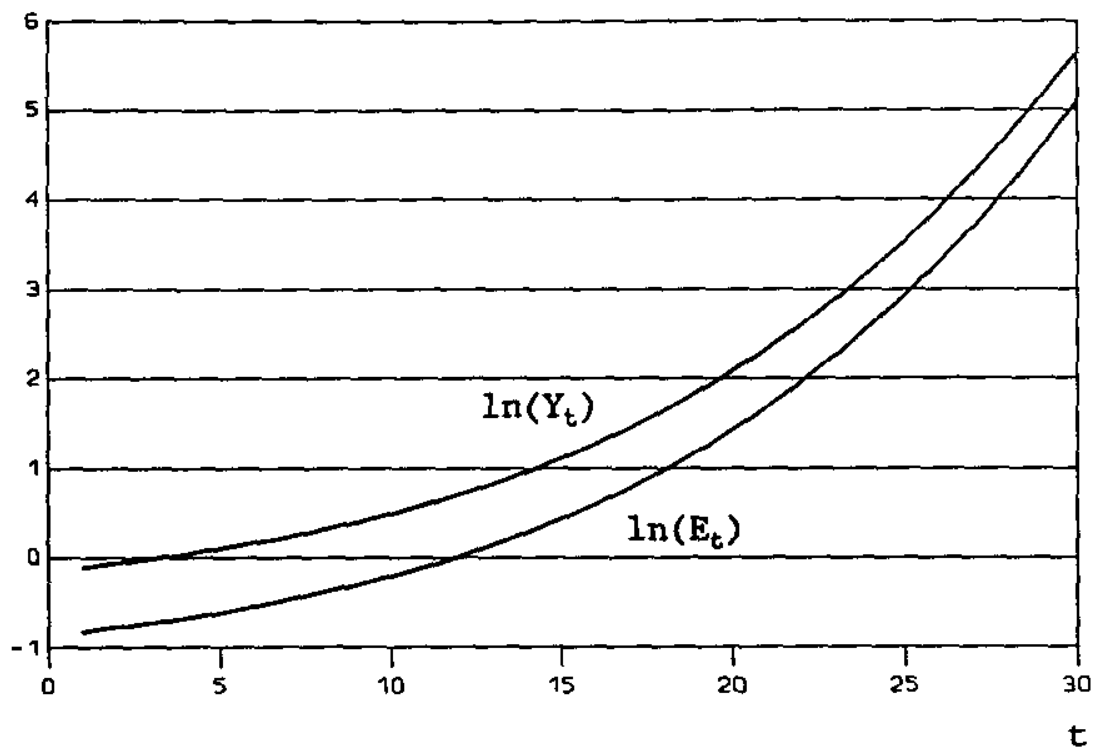

b. Time allocated to schooling and tax rate

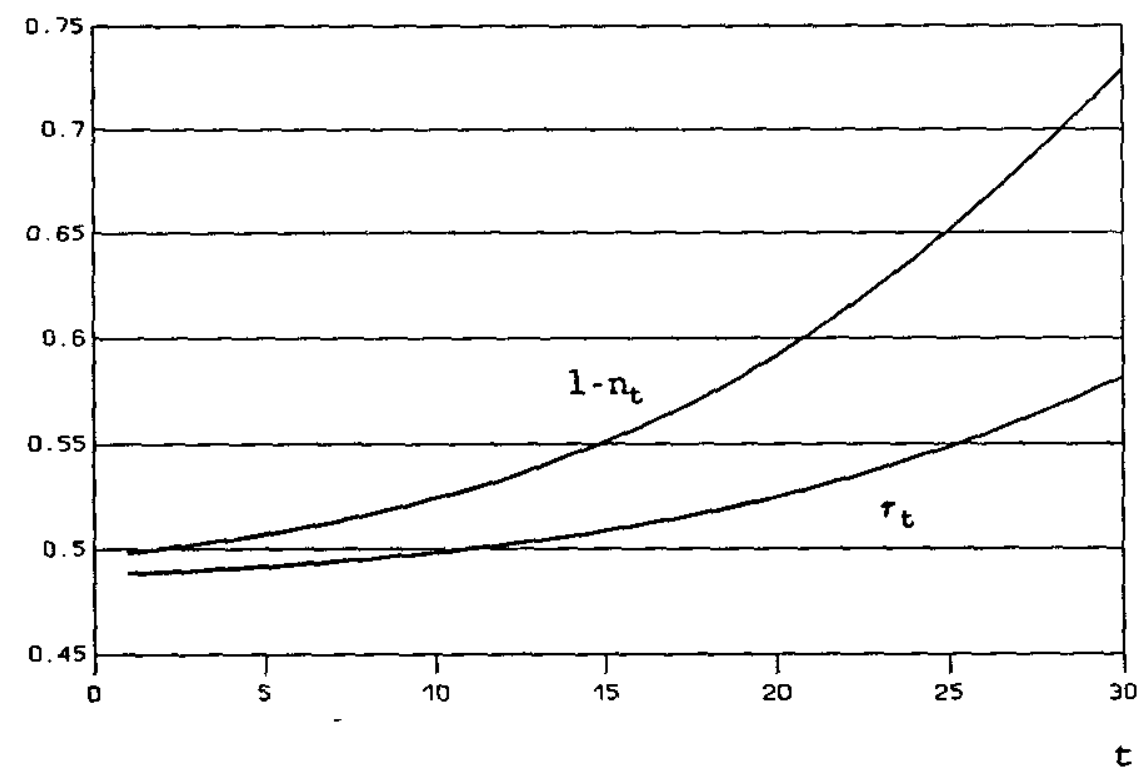

Figure 8. Time series predictions: $\phi<\sigma$ 
a. Per capita income and public expenditures on education

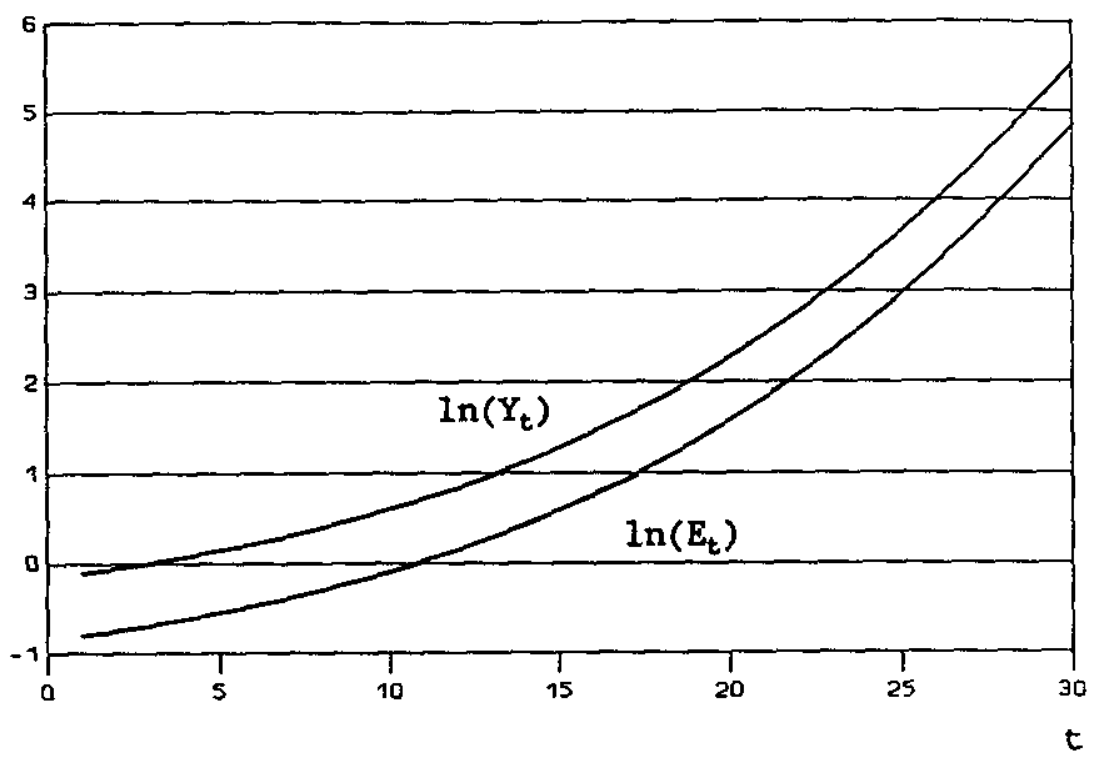

b. Time allocated to schooling and tax rate

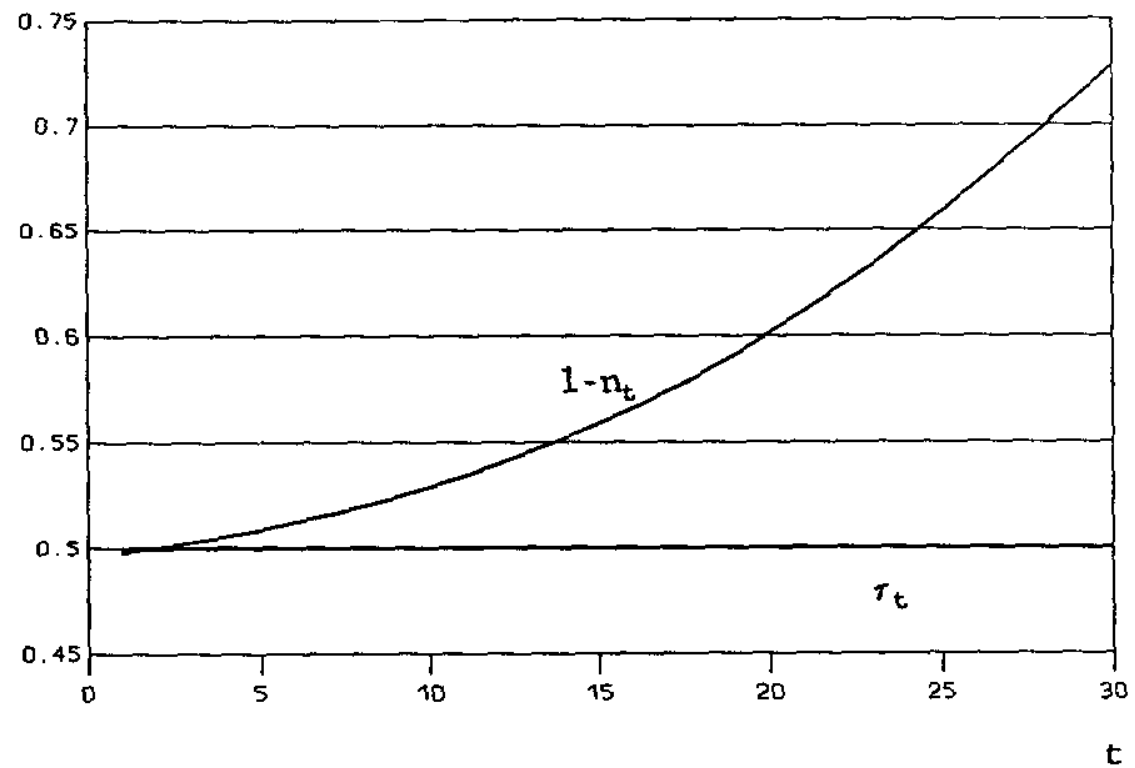

Figure 9. Time series predictions: $\phi=\sigma$ 